\title{
El Profano y la Ley en Inglaterra
}

\section{INTRODUCCION}

La consideración que el pueblo inglès siente por la ley y la profesión forense no rebasa el grado de afecto que por ellas tienen, o han tenido, otras naciones. Es un hecho que el ciudadano corriente, profano en materias jurídicas, abriga una animadversión perenne frente a los tecnicismos y sutilezas del derecho que, $\alpha$ veces, tienen por consecuencia aparente divergencias desafortunadas entre la justicia y la justicia administrada conforme a la ley. Si bien nuestros antiguos jurisprudentes, empezando por Fortescue, elogiaron de manera desmesurada la totalitad de las instituciones jurídicas inglesas (lo que provocó la ira de iconoclastas reformadores, entre ellos Bentham), los novelistas ingleses no han prodigado los retratos lisonjeros de abogados. Por otra parte, preciso es confesar que en el desarrollo jurídico de Inglaterra ha habido largos períodos durante los cuales las censuras de los críticos y escritores satíricos - citemos a Charles Dickens- estaban sobradamente justificadas. Incluso en la actualidad, cuando se ha eliminado la mayoría de los abusos intolerables del pasado el derecho (por lo menos, el civil) no es una institución simpática para el ciudadano británico debido $\alpha$ su costo que, a pesar de las recientes medidas encaminadas a hacer asequible la asistencia jurídica a personas de medios reducidos, todavía sigue siendo elevado en comparación con muchos otros países.

Sin embargo, no hay duda de que los ingleses se enorgullecen de su sistema jurídico, hasta el punto de creerlo - al estilo del Sr. Podsnap creado por Dickens - el mejor y. más justo de la tierra, sin comparación posible. Por supuesto, esta opinión demanda en gran medida de la conocida mentalidad insular del pueblo inglés, aunque hay tambén razones que la abonan, en especial el elevado prestigio de que vienen gozando desde hace unos 800 años los jueces de nombramiento real, a los que ahora llamamos magistrados del Tribunal Supremo (1). Su nombramiento se efectúa de

1. En la actualidad, el Tribunal Supremo (o, con mayor propiedad, el Tribunal Supremo de Judicatura) se compone de 41 magistrados. si se execeptúa al Archivero Mayor y a los 8 Lores Magistrados (todos los cuales son ascendidos a la categoría de magistrado inferior) que torman el Tribunal de Apelación. La Sala denominada "Queen's Bench Division" está compuesta del Presidente del Tribunal Supremo y de otros 24 magistrados; la Sala de "Chancery Division". 
una manera que debe parecer sumamente irracional a muchos extranjeros. En Inglaterra no hay un Ministro de Justicia, cuya posib:e creación despierta poco interés popular; hay sin embargo quien aboga por ella. Los magistrados son nombrados por el soberano por recomendación del Lord Canciller, quien somete una nómina de candidatos escogidos enteramente $\alpha$ discreción propia de entre los miembros del Foro; jamćs se dan a conocer cuáles fueron los consejos escuchados ni los criterios de selección aplicados. Una vez nombrado, el magistrado es inamovible mientrás su comportamiento se ajuste a los dictados de la moral $y$, desde que en 1702 la Ley do Establecimiento independizó al poder judicial del favor real o de los políticos, ningún juez inglés ha sido destituído por incompetencia o mala conducta. El juez rige su tribunal como monarca absoluto $y$ es tratado por los abogados con la mayor deferencia; en opinión de algunos críticos del sistema, con una deferencia excesiva que fomenta su vanidad. Tiene facultades para imponer castigos severos por cualquier acto de rebeldía o falta de respeto hacia el tribunal. En las vestiduras oficiales $y$ en el protocolo judicial se observan muchos ritos tradicionales que realzan la dignidad del cargo, al que va inherente al título de caballero $y$, en el caso del Tribunal Supremo, el de Par del Reino. Dentro de límites muy vastos no puede ser objeto de crítica, bajo pena de ultraje a la justicia. Considerado únicamente como símbolo de la "majestad de la ley", el juez es una figura impresionante $\mathrm{y}$ hasta decorativa, $\mathrm{y}$ así le considera el ciudadano británico medio.

El respeto que se tiene por el juez es un rasgo común de todos los tribunales de Inglaterra, incluso de los muchos tribunales correccionales, descritos más adelante, que en su mayoría están formados por ciudadanos ordinarios. Es raro que un tribunal se vea obligado a imponer una medida disciplinaria a un abogado, litigante, testigo o acusado impertinente. Todo el mundo cree que esta actitud general facilita enormemente la administración de justicia, indicio como es de la confianza que el pueblo siente por su espíritu y modo de actuar.

Entre las muchas que podrían mencionarse, es necesario poiner de relieve tres consideraciones generales con que el ciudadano concurre $\alpha$ los tribunales y cuya validez da, en realidad, por descontado.

En primer lugar, está seguro de que el juez será totalmente imparcial. De todas las reglas de justicia natural - que se formulan en Inglaterra de manera algo vaga y cautelosa-, ninguna se exige con mayor rigor que la relativa a la falta de prejuicios y a la ausencia de la menor sospecha al respecto. Ningún cliché jurídico se cita con mayor frecuencia que el de "hágase justicia y hágase ver que se ha hecho justicia". $\AA$ veces, se da a este principio una interpretación exagerada, aunque en sí mismo responde indiscutiblemente a una doctrina sana. Por otra parte, se considera fundamental que no se influya, de palabra o de hecho, en un sentido o en otro,

de 7 magistrados, y la Sala de "Probate, Divorce and Admiralty Division", del Juez Presidente $\mathrm{Y}$ de 8 magistrados. Además de despachar negocios en Londres, todos los jueces, excepto los que componen la "Chancery Divison", ejercen periódicamente sus funciones en los tribunales sesionales (Assires) que tienen competencia en materia civil, penal $y$ matrimonial. A menudo, los jueces han sido escogidos de entre los miembros del Colegio de Comisiones. los cuales gozan del mismo rango mientras dsempeñan el cargo. 
sobre el curso de la justicia. Se tienen por ultraje grave al tribunal los: comentarios públicos, en especial los que prejuzguen el fallo, relativo a toda causa que esté sub judice, $y$ sus autores son castigados de manera expeditiva y severa. A este respecto, Ias costumbres inglesas contrastan acusadamente con las de los Estados Unidos y de otros muchos países. Nada aborrece mós la opinión inglesa que los "juicios ante el tribunal de la prensa"".

En segundo lugar, la persona acusada de haber violado las leyes penales tiene la confianza de ser absuelta a menos que la acusación pruebe: lo imputado sin dejar ninguna duda razonable. En todo juicio criminal, el juez y los abogados, tanto de la defensa como de la acusación, se refieren una y otra vez a este principio. Según las normas contemporáneas de etiqueta forense, no incumbe al representante de la Corona tratar de que se condene al reo por todos los medios posibles y está mal considerado profesionalmente que la acusación emplee invectivas, tal como se hacía en tiempos pasados: si así se hiciera, ello podría incluso predisponer a un Jurado en contra del abogado que utilizara tales métodos. El "deber de probar" es un pilar granítico del derecho penal.

En tercer lugar, el ciudadano británico, el cual considera que en términos generales los tribunales son los medios de defensa de sus derechos, confía en particular en que se encarguen de proteger su libertad personal. Montesquieu, al estudiar el sistema constitucional de Inglaterra en un momento crucial de su historia, expresó la opinión de que el genio nacionaI británico consistía on un anhelo de libertad. Quizás no pueda afirmarseque este aserto es vólido para todos los períodos de la historia de Inglaterra, pero en derecho moderno inglés - por más que ello sea sólo el resultado final de una larga lucha - los "derechos naturales" de la persona son especial objeto de atención y defensa. El habeas corpus a pesar de que su reconocimiento ha sufrido altibajos, es un baluarte sólidamente establecido desde antiguo, $y$ es significativo que toda demanda que se presente $\alpha$ un tribunal inglés concerniente a la "libertad de un súbdito" pasa a primer lugar entre los trabajos judiciales. Como veremos, toda actuación policíaca que rebase las atribuciones de las fuerzas del orden provoca una reacción popular fuerte inmediata, que por lo común halla expresión en el Parlamento. La detención ilegal, incluso la practicada durante un brevísimo período de tiempo, es un delito contra la persona por el que puede condenarse al pago de una indemnización muy crecida. La ley defiende con casi el mismo ahinco el buen nombre y la libertad; la ley inglesa es, en materia de difamación, una de las más severas del mundo y no es raro que una persona cuya reputación ha sido empañada, en particular si ello ha ocurrido por obra de un periódico, reciba por decisión de un Jurado británico una indemnización de un importe considerable. En todas las materias mencionadas, el ciudadano británico considera que los tribunales son los órganos encargados de velar permanentemente por su protección.

Estos son, pues, algunas de las notas que caracterizan las relaciones de los anglosajones con la ley, y se ha hecho mención de ellas porque, por su misma naturaleza, se reflejan en los casos en que el ciudadano profano en materia jurídica participa en la administración efectiva de la justicia. Este es el tema que se estudia a continuación. 


\section{El Jurado}

El primero de tales casos, y el más caracterizado, se da cuando se convoca $\alpha$ un ciudadano para que sirva de jurado, tal vez en un pleito civil ventilado ante el Tribunal Supremo o un tribunal de condado, aunque es más probable que se trate de un proceso en el que se enjuicia a un delincuente ante uno de los tribunales penales superiores.

El inglés medio considera que el "juicio por jurados" es una institución característicamente británica y quedará sorprendido si oye decir que, según la mayoría de los historiadores, es en su origen una importación extranjera por la cual el pueblo inglés ha quedado en deuda con su único Conquistador. El Jurado ha pasado por transformaciones notables que no pueden ser descritas en la presente ocasión. Expuesto a grandes rasgos, el Jurado empezó por ser un grupo de testigos procedentes de una localidad que, debido a esta característica común, tenían conocimientos especiales sobre determinada cuestión, y se ha convertido en un órgano de doce ciudadanos (nadie sabe por qué deben ser doce, aunque se han formulado muchas hipótesis al respecto) (2) que, muy lejos de ser testigos, no deben saber nada en absoluto acerca del caso de que se trate, sino que deben formaîse una opinión basándose en lo que se revele en el curso del juicio. Toda tentativa para suministrar a un jurado información a título privado o cuyo objeto sea influir sobre su ánimo por medio del soborno o las amenazas - por cualquier otro medio se considera como delito de embracery (cohecho). Al prestar juramento, el jurado se compromete a "atenerse a las pruebas" $y$, de conformidad con esta norma, a pronunciar un veredicto justo, que sólo puede ser el de "culpable" o "no culpable" (3). El Jurado debe llegar a una conclusión por unanimidad. En un pleito civil, las partes pueden. aunque ello no sea obligatorio, aceptar un veredicto aprobado por mayoría de votos. Sin embargo, en Inglaterra (en Escocia es distinto) no puede dictarse sentencia en una causa criminal, si el veredicto no se aprueba por unanimidad. En el caso de que un Jurado no pueda emitir un veredicto unánime. debe celebrarse un nuevo proceso ante otro Jurado $y$, si después del segundo juicio no hay todavía acuerdo, es corriente que la Corona incoe un nolle prosequi. lo que equivale de hecho a abandonar la acusación. En lo que se refiere ai veredicto, no se requiere, ni se permite, que los jurados expongan sus motivos, aunque tienen la facultad, dentro de ciertos límites, para añadir una cláusula adicional en la que se recomiende por ejemplo que se tenga merced con el reo convicto o se llame la atención de las autoridades hacia una característica del caso que reviste particular interés para el público.

2. En los tribunales de condado, los jurados deben ser ocho por oscuras razones de orden histórico. Como veremos, el número de jurados es diferente en otras jurisdicciones, entre ellas las de los coroners y an las investigaciones de demencia.

3. En Inglaterra se desconoce el veredicto de "no probado", propio del deracho escocés. Si pronuncia el veredicto "especial" $y$ en apariencia contradictorio de "culpable pero demente". el Jurado declara haber llegado a la conclusión de que el acusado cometió el hecho punible atribuído $\sin$ que le quepa, empero, responsabilldad. El reo es internado, mientras así lo quiera la Reina (es decir, en la práctica mientras el roo no recobre su sano juicio), on una institución especial para "demented criminals". 
Si el veredicto de culpabilidad no se ajusta al derecho por ser "contrario al resultado de las pruebas", puede ocurrir (aunque raras veces sucede) que sea anulado por el Tribunal de Apelación Penal, pero en tal caso los jurados ya no incurren, como antes, en el delito llamado de obduracy (obstinación). No cabe recurso de apelación contra un veredicto injusto de absolución.

Los requisitos que se exigen de los jurados son extrañamente arcaicos; no han sido modificados desde 1825. El jurado, masculino o femenino, debe figurar en el registro electoral y debe tener 10 libras esterlinas de renta líquida anual mínima procedentes de bienes de propiedad (freehold); 0 bien tener una renta anual de por lo menos 20 libras esterlinas, producto de bienes sobre los que se tiene un derecho real (leasehold) por un plazo mínimo de veintiún años; o bien tener domicilio propio (household) por el que se pague un inquilinato mínimo de 30 libras esterlinas en Londres o en el condado de Middlesex o de 20 en otro lugar del país. En las listas de electores se indican las personas que reúnen estas condiciones y de entre ellas se escogen los jurados por medio de procedimientos que sería enojoso describir. Debido a los cambios experimentados por el valor de la moneda desde 1825, tiene poca importancia el requisito de ser propietario, que en otras esferas legales no se considera actualmente como una ventaja y que ha desaparecido de las condiciones exigidas para adquirir el derecho al voto. En cambio, la limitación de tener domicilio propio excluye a buena parte de la "población flotante" $\mathrm{y}$, lo que es tal vez más importante, exime también a la mayoría de las mujeres casadas, muchas de las cuales serían jurados muy competentes (4).

Todavía más notables que estos antiguos requisitos son las incompatibilidades por las que una persona queda dispensada de prestar servicio como jurado. Estas incompatibilidades fueron puestas en vigor en virtud de la Ley de los Jurados de 1825, antes de cuya fecha no parece que existieran incompatibilidades de ningún género. Quedan exentos, además de funcionarios de muchas clases, todas las personas que ejerzan una carrera jurídica, médica o religiosa, todos los pares del Reino y los diputados y todos los miembros de las fuerzas armadas. Sin duda, el poder legislativo ha creído que las enumeradas son ocupaciones que no deben ser interrumpidas por los deberes, a veces duros, de los jurados, pero es difícil descubrir por qué esta consideración no se aplica con igual razón al comerciante o tendero cuyos intereses pueden quedar sumamente perjudicados por haber estado ausente largo tiempo de la dirección del negocio. Otro anacronismo es el de excluir todas las personas mayores de sesenta años (el límite inferior de edad se fija en veintiún años). Que sepa el autor de este trabajo, no se da otro caso en el que se suponga actualmente que los sesenta años marcan el límite de eficiencia; la norma es tanto más inadecuada cuanto que, aparte de tener mayor experiencia, los hombres y mujeres de edad avanzada tienen probablemente más tiempo para actuar como jurados que los jóvenes que todavía no han llegado a una situación profesional estable.

En contraste con las dispensas y excepciones referidas, las personas de antecedentes penales conocidos no están excluídas. Quedó decidido en

4. So describe más adelante la participación de la mujer en los Jurados. 
fecha tan reciente como 1950 (5) que un criminal convieto o, para el caso, una persona que ha pasado la mayor parte de su vida en prisión tiene derecho a servir de jurado (aunque, por supuesto, se pueda pedir su exclusion si la defensa conoce sus antecedentes).

Sería preciso, en apariencia, renovar todo el sistema, pero no se aprecia ninguna corriente popular en pro de una reforma. En general, el privilegio, o deber, de prestar servicio como jurado no es, al contrario de lo que se cree a menudo, uno de los atributos de la condición de ciudadano, ni por su frecuencia, ni por su extensión. Según la mordaz expresión acuñada por el magistrado Devlin. (6) el Jurado británico "no es representativo del conjunto de los ciudadanos. Predominan los hombres de mediana edad, de mentalidad promedia y de clase media". Se considera de modo proverbial que el "término medio" ofrece la mayor seguridad posible (aunque el auiomovilista moderno quizás no piense lo mismo del curso medio de una carretera) y es uno de los lugares comunes del pueblo británico decir que la clase media constituye la "espina dorsal de la nación". Esta mediocridad garantiza tal vez que prevalecerá el sentido común promedio, o sea la cuáidad que mós comúnmente se atribuye al Jurado y se espera de él. Sin embargo, un ciudadano britónico puede vivir toda su vida sin que jamás se le requiera para prestar servicio como jurado $y$ es raro encontrarse con alguièn que haya sido convocado más de una vez.

Entre las personas que parecen considerar satisfactoria la institución del Jurado, está el acusado. Tiene derecho a poner siete recusaciones vagas de jurados - o sea, sin necesidad de expresión de causa - y puede proponer un número ilimitado de recusaciones fundadas - esto es, por motivos que el reo alega y que deben ser examinadós y decididos con arreglo a un procedimiento arcaico que tiene por nombre voir dire. Por consiguiente, si así lo desea, el acusado o su abogado pueden recurrir a tácticas dilatorias que tal vez perturben de manera considerable el funcionamiento del tribunal. Como es sabido, en los Estados Unidos métodos de este tipo entorpecen, a veces de modo notable, la administración de justicia. En Inglaterra, esta facultad es casi letra muerta; las recusaciones son muy raras y se ha visto muy pocas veces que demoraran un juicio. Si se emplearan habitualmente, sería difícil, acaso imposible, que los tribunales penales ingleses pudieran llevar a cabo su labor.

Según la expresión ya consagrada, el Jurado tiene por función decidir las cuestiones de hecho, mientras que incumbe al juez resolver los puntos de derecho. Sin embargo, esta dicotomía no es tan clara como parece a primera vista. Cualquier abogado sabe que en muchos casos el derecho $\mathrm{Y}$ el hecho están confundidos de manera tan intima que es imposible distinguirlos exactamente. En un caso concreto, esta situación puede resolverse por un juez inglés mediante la aplicación de una facultad muy importante. Una vez que la acusación a formulado su primer alegato, la defensa puede pretender que las declaraciones de los testigos de la Corona no demuestran

5. R. v. Kelly, 1950) 2 Q.B. 164.

6. Trial by Jury, 20. 
la existencia de un "hecho del que deba responderse", o sea que las alegaciones, incluso si no son objeto de réplica, no demuestran que el hecho atribuído constituya delito. En realidad, el magistrado asume entonces el papel de juez de hecho; puede decir que, consideróndolo como cuestión de derecho, el Jurado no puede ni debe hallar al procesado criminalmente responsable del hecho punible que le atribuye la acusación. El magistrado "declara al Jurado incompetente para tratar del juicio" y dispone que emita al propio tiempo un veredicto de no culpabilidad. Se produce entonces una situación curiosa. Por una parte, un juicio por jurados no puede terminar sinu por un veredicto $y$, por otra, el Jurado no tiene la obligación de obedecer al juez. Es una hipótesis discutible qué ocurriría si el Jurado-desafiara al juez, aunque, de hacerlo así, los componemtes del Jurado no se expondrían ciertamente a ser sancionados. Sin embargo, este caso no sucede nunca en la práctica y sería difícil encontrar un ejemplo en la época moderna do un Jurado que ha ignorado las instrucciones dadas por un juez sobre una cuestión de derecho, aunque tales instrucciones han sido probablemente mal interpretadas en muchos casos. El Jurado tiene una facultad pareja a la del juez, ya que, si considera que lo alegado por la acusación no tiene fundamento, puede por decisión propia "suspender el juicio" al indicar que no desea que la defensa presente medios de prueba.

Huelga decir que estos casos son raros, porque corrientemente no se formulan acusaciones basadas en fundamentos tan débiles que puedan ser desechados inmediatamente de la manera referida. Suponiendo que el proceso siga un curso normal y que ambas partes expongan en su integridad sus argumentaciones al Jurado, es costumbre seguida modernamente (que no se remonta más allá del siglo dieciocho) que el juez resuma los puntos de derecho y los hechos.

Como es natural, el procedimiento para resumir difiere de un juez $\alpha$ otro. La recapitulación perfecta es aquélla en que, a la vez que se explican de la manera más sencilla posible cuáles son las leyes aplicables, se llama la atención del Jurado hacia los aspectos de las pruebas que revisten mayor importancia para determinar si existe o no culpabilidad. En teoría, la exposición del juez debiera ser imparcial en absoluto, pero es humanamente imposible que un juez analice un conjunto de hechos y las interpretaciones contradictorias que los abogados han deducido de ellos ante los jurados en forma en que no se vislumbre por lo menos, una indicación de su propia opinión. La fórmula corriente del juez: "Miembros del Jurado, tal vez opinen ustedes que..." equivale $\alpha$ menudo $\alpha$ decir en realidad: "tiene que ser evidente para ustedes, a menos que sean muy estúpidos, que..." Por lo común, no es muy difícil decir que el juez ha resumido en favor o en contra del reo. Si el juez es evidentemente hostil al acusado y da la impresión de que quiere condenarle a toda costa, es un lugar común entro letrados que con probabilidad el Jurado hará frente al juez y emitirá por su parte un veredicto de absolución. Sin embargo, a pesar de que no haya dudas sobre cuál sea su opinión, el juez debe formular siempre determinadas advertencias en favor del acusado, bajo pena de revocación de la sentencia por el Tribunal de Apelación Penal. Se ha mencionado ya la más corriente de estas advertencias: insistir en que el deber de probar incumbe a la acu- 
sación. También debe formularse de manera virtualmente obligatoria otra advertencia: desconfiar del testimonio de los cómplices, del no confirmado por otros medios (en especial si se trata del testimonio de menores) y del de mujeres en el caso de delitos contra la honestidad. Cuanda un juez advierte que "no es aconsejable emitir un veredicto de culpabilidad" habida cuenta de lo incierto de las pruebas, es casi seguro que se pronuncia a continuación un veredicto de absolución.

En vista de que es prácticamente imposible eludir la posibilidad do expresar una opinión en cierta medida subjetiva, en algunos países (por ejemplo, muchos de los Estados Unidos) se prohibe que el juez resuma los hechos y se ordena que su función se limite a citar las leyes pertinentes. En Inglaterra, no parece que se desee cambiar el sistema actual, pero como nadie sabe qué ocurre en la sala de jurados, es difícil formarse una opinón general acerca de los efectos que la recapitulación ejerce sobre la mente colectiva del Jurado. Cabe cor. todo dar por supuesto tres hechos: primero, el Jurado escuchará al juez con respeto y atención; segundo, aceplará sin reservas y tratará de comprender el alcance de las disposiciones lega'es citadas por el juez (nadie sabe en qué medida ello se logre), y, tercero, no dejará en modo alguno que se le coaccione a pronunciar un veredicto que esté en pugna con su conciencia y entender. La recapitulación es el "punto final del juicio. Tanto si los abogados han utilizado argucias retóricas como argumentos plausibles, el análisis sereno y distante de un juez experimentado es un antídoto saludable que facilita el que las deliberaciones de los jurados se celebren en un ambiente de equilibrio mental entre los ingeniosos alegatos contradictorios presentados por los representantes de las partes.

Resumir de manera completa y clara no es tarea fácil. Es muy corriente que, al apelar, se alegue que el juez encauzó de manera indebida la opinión del Jurado, a menudo en un punto de índole muy especializada, y algunos jueces tienen siempre tan en cuenta la presencia invisible del Tribunal de Apelación Penal que sus instrucciones se limitan a ser una exposición de advertencias y de suposiciones tan finamente matizadas que sólo provocan perplejidad entre los jurados. Sin embargo, en conjunto los métodos que los jueces utilizan para reşumir están muy perfeccionados $y$ tienen por objeto llegas a una conclusión justa.

En años recientes, la institución del Jurado británico ha sido estudiada a fondo por dos juristas eminentes en dos ciclos de conferencias dictadas bajo los auspicios de la fundación Hamlyn. El magistrado Devịn desarrolló el tema de "El juicio por jurados" $\mathrm{y}$ el doctor Glanville Williams se ocupó de "Las pruebas de eulpabilidad". A pesar de no abrigar ilusiones sobre los defectos del Jurado, sir Patrick Devlin pareció inclinarse en conjunto por considerar la institución como un elemento útil del sistema de administración de la justicia penal. El doctor Williams, que preferiría ver establecido el sistema continental europeo del juicio ante un "colegio" de jueces o ante un magistrado asesorado por consejeros legos, expresa un punto de vista mucho más crítico. En opinión del autor del presente artículo muchas de sus censuras estón bastante justificadas. El doctor R. M. Jackson (7) no es menos excéptico que el doctor Williams.

7. The Machinery of Justice in England (2 edición, 1957). 
En cierto sentido, el Jurado ha sido, con respecto a sí mismo, su crítico más severo, ya que en los años pasados su competencia ha disminuído de manera notable, sin que ello suscitara ninguna protesta entre el público. Con anterioridad, el Gran Jurado, esto es, el Jurado de acusación, examinaba todas las actas de procesamiento para determinar, bajo la dirección de un magistrado de un tribunal de sesiones (Assize), si había o no lugar a proceder criminalmente - es decir, si había o no indicios prima facie de culpabilidad - y ofrecía también una oportunidad al magistrado para pasar revista en términos generales a la situación existente en materia de orden público. Sin embargo, hacía tiempo que sus funciones habían sido asumidas por los jueces de instrucción (cuyos cometidos se estudian más abajo) y en cierta medida por el Director of Public Prosecutions (Primer Fiscal del Estado). El Gran Jurado se convirtió en una meru reliquia pintoresca y algo cara, que fue abolida en 1933 (8). No obstante, existe todavia el Jurado do juicio que, en rigor, no es ya el Jurado Menor, tal como había sido denominado durante siglos para distinguirlo del Gran Jurado. En la práctica, ha desaparecido también la distinción entre "Jurado especial" y "Jurado común". En el primero se exigían ciertas condiciones más estrictas que en el Jurado común en lo relativo a títulos profesionales y a la calidad de propietario $y$, desde 1949, (9) el Jurado especial sólo examina conflictos mercantiles en la ciudad de Londres. En el terreno práctico, son raras las veces que se reúne incluso para ocuparse de asuntos de jurisdicción particular, ya que los hombres de negocios parecen preferir la decisión de un solo magistrado $o$, con mucha mayor frecuencia, recurrir a los buenos oficios de un árbitro en lugar de litigar. Sin embargo, la actuación del Jurado ha disminuído de manera más marcada en la esfera de las acciones civiles corrientes, entre ellas las muchas en que se alega negligencia $y$ en que las pruebas aducidas están a menudo totalmente en pugna unas con otras. Según las normas vigentes, el magistrado está facultado para decidir si hace falta reunir un Jurado (casi nunca hace uso de tal atribución), aunque en determinadas clases de pleito cada una de las partes tiene derecho a solicitar que el juicio se celebre ante el Jurado. En términos generales algunas demandas contienen referencias personales que afectan el buen nombre de la persona objeto de la demanda: defraudación, acusación falsa, injuria, calumnia, seducción, ruptura de la promesa de matrimonio. Un cínico quizós atribuye cierto significado al hecho de que en esta clase de litigios los llamamientos retóricos o sentimentales pueden hallar el camino abierto para sobreponerse $\alpha$ un espíritu impresionable. Para decirlo con franqueza rayana en la brutalidad, en tales litigios el abogado del demandante persigue a menudo el propósito de "redondear" el importe del resarcimiento pecuniario echando mano de consideraciones emotivas que, jurídicamente, no tienen que ver con la cuestión o que, en el mejor de los casos, sólo guardan con ella una relación fortuita. Este no es un comentario muy halagador respecto del pretendido "sentido común" del Jurado.

8. Administration of Justice (Miscellaneous Provisions) Act. 1933. Ley de la Administración de Justicia (Disposiciones varias).

9. Juries Act, 1949 (Ley de los Jurados): 
A pesar de que ha disminuído de manera marcada el papel desempeñado por el Jurado con los pleitos civiles, hay una modalidad de procedimiento legal en la cual el Jurado es todavía un factor importante, a saber, en las encuestas realizadas por los coroners (oficiales criminalistas) para averiguar la causa de "muertes violentas o no debidas a una causa natural". Es ésta una institución antiquísima del derecho inglés, que se remonta ciertamente al siglo XIII (4 Edw. I, 1276) y quizás ontes. Actualmente, la encuesta está regulada por las Leyes de 1887 y de 1926 y por un conjunto de reglamentos, el más reciente de los cuales fue puesto en vigor en 1953. En virtud de la legislación vigente, el coroner está obligado a convocar un Jurado de encuesta si tiene razones para creer que la muerte de una persona ha sido causada con intención culpable (asesinato, homicidio o infanticidio), o en un accidente ferroviario, aéreo o automovilístico, en determinados accidentes de trabajo o por ciertas enfermedades profesionales, o en circunstancias que ponen en peligro la "salud o higiene públicas", o cuando la muerte ha tenido lugar en un establecimiento penitencicrio (incluso en los casos de cumplimiento de la pena de muerte). Si bien esto quiere decir que se deben constituir Jurados para muchas encuestas, en muchas otras no es necesario hacerlo. El Jurado debe estar compuesto por "hombres buenos y respetuosos de la ley"( hoy día se admite también $\alpha$ las mujeres) y es costumbre que sean escogidos entre los avecindados en las cercanías inmediatas al lugar del fallecimiento. Su número no puede ser inferior $\alpha$ siete, ni superior $\alpha$ once $y$ no es necesario que emitan una. opinión unánime; el coroner puede aceptar un veredicto aprobado por mayoría si la minoría disidente no rebasa el número de dos votos. En lo principal, las condiciones y dispensas son las ya mencionadas, pero hay ciertas diferencias derivadas de distinto desarrollo histórico. Así, por ejemplo, no. hay límite de edad, ni superior ni inferior (aunque sería inaudito que se convocara $\alpha$ personas de menos de 21 años) y no existe derecho de recusación ya que, por supuesto, no hay nadie sometido a juicio. El veredicto de un Jurado convocado por un coroner puede tener gran importancia porque, si se estima que existe responsabilidad criminal, en especial en el caso de homicidio, por parte de una a la que se nombra, tal persona puede ser procesada inmediatamente por el coroner, quien asume así las funciones de juez de instrucción. Al resumir ante el Jurado el derecho y las pruebas, los coroners siguen un procedimiento parecido al de los magistrados.

Otra función que históricamente incumbe a veces a los coroners es investigar los hallazgos de tesoros ocultos. Esta clase de encuesta tiene por objeto decidir, con arreglo a determinados principios de derecho que no es preciso exponer aquí, si debe adjudicarse a la Corona o al descubridor el tesoro oculto o enterrado (cuya antigüedad es a veces remota). En estas encuestas, es necesario también convocar un Jurado ordinario de coroner.

En los tribunales de condado, los juicios pueden celebrarse ante un Jurado de la misma manera que en el Tribunal Supremo, salvo en lo relativo al número de jurados que sólo es de ocho. No obstante, los tribunales de condado sólo conocen de causas civiles y en ellos los jurados actúan todavía con menos frecuencia que en los lítigios de jurisdicción civil del Tribunal 
Supremo. El Jurado acthúa en otras pocas esferas a las que sólo es necesario referirse brevemente. Puede ser reunido a discreción en raros casos en juicios de testamentaría, en los conflictos relativos a una acta de última voluntad Es muy poco frecuente hoy día en las peticiones de divorcio, aunque puede utilizarse este procedimiento en los pleitos muy disputados, en especial cuando se reclaman perjuicios contra el correo en el caso de pretendido adulterio de la esposa. Sea por petición de la persona a la que se pretende demente o a discreción del magistrado, puede reunirse un Jurado, compuesto a lo más por 24 personas y a lo menos por 12, para celebrar una investigación judicial de demencia, aunque ello no es corriente en modo alguno. Por razones de carácter histórico, el Jurado no ocupa lugar alguno en la jurisdicción de la sala de "Chancery Division", ni actúa hoy día en los juicios vistos ante la sala de "Admiralty Division", aunque en esta jurisdicción el magistrado puede, como veremos, actuar acompañado por peritos náuticos que le asesoran en cuestiones técnicas.

Por consiguiente, la institución del Jurado ha perdido en conjunto mucho de la importancia que antes tenía en el derecho inglés. Inciuso en la jurisdicción penal, sus funciones han disminuído de manera notable. Como se expone en este mismo trabajo, en Inglaterra la misma mayoría de los juicios penales no son fallados jamás por un juez con jurados, sino que son vistos y resueltos por magistrados. En una considerable mayoría de los procesos penales celebrados ante los tribunales superiores porque así lo exija la ley o porque lo escoja el acusado, el reo se declara culpable. En tal caso, no hay que reunir ningún Jurado $Y$ sólo es necesario que el tribunal dicte sentencia.

Sin embargo, si bien este tamoso "baluarte de la libertad" ha perdido en tiempos recientes parte de su antiguo prestigio, todavía se le rinden homenajes encendidos. Muchos magistrados y jurisconsultos de gran experiencia reafirman constantemente su creencia en la sabiduría del Jurado, y no es posible ignorar como de poca importancia el testimonio de tales personalidades, a pesar de que muchas veces tales afirmaciones no concuerdan con los ejemplos de buen sentido o de seriedad dados por los jurados. ¿Cuál es la opinión de los jurados sobre su aportación a la administración de justicia? La justicia no ha tratado nunca con gentileza a sus ayudantes legos. En el pasado, se sometía a los jurados a toda clase de incomodidades físicas con el objeto de obligarles a concluir rápidamente su misión. Incluso en la actualidad se ha hecho poco para que su suerte sea más llevadera y sólo desde 1949 se concede a los jurados indemnizaciones para resarcirles por el tiempo y los ingresos perdidos (10). En algunos juicios celebrados modernamente, en especial en los casos de defraudación comercial, los jurados son retenidos y separados del resto de la comunidad durante muchos días. Es dificil formarse una opinión sobre la actitud de un jurado

10. Asignaciones de viaje $y$ de manutención $y$ una indemnización, cuyo importe se fija de conformidad con una tarifa estatutaria $Y$ sujeta a determinadas condiciones, por razón de pérdida de ingresos y por gastos especiales (Leyes de los Jurados de 1949 y 1954). Estas Leyes tienen simplemente por objeto reintegrar los gastos menudos; los jurados no perciben remuneración por los servicios prestados, que son considerados como una obligación cívica. 
respecto de su ingrato deber cívico. El doctor Williams sugiere que en su mayoría los jurados se sublevan ante la mera posibilidad de ser convocados. En cambio, Sir Patrick Devlin estima que el ciudadano corriente acepta complacido la oportunidad que se le ofrece de ayudar al funcionamiento de un servicio público vital, incluso a costa de su propia conveniencia. Se dice que la experiencia estimula el sentido de responsabilidad cívica y que, dado por lo común que el ciudadano no está familiarizado con los procedimientos jurídicos la ocasión tiene quizás el atractivo de la novedad. Lo más probable es que sea imposible generalizar y que distintos individuos tengan una opinión distinta sobre los deberes de los jurados, según sus propias circunstancias y tal vez sus temperamentos. No parece demasiado crenturado decir que pocos jurados desempeñan sus obligaciones, cualquiera que sea la actitud con que las acepten, con desinterés o impaciencia.

Sean cuáles sean los puntos débiles del Jurado e incluso en el caso de que su renombre se base parcialmente en mera superstición (como el doctor Williams parece sugerir), no puede apenas dudarse que el público en general cree como articulo de fe gue la institución funciona de manera adecuada y que cualquier propuesta encaminada $\alpha$ enmendarla o a abolirla se entrentaría con una resistencia tenaz. Este no es simplemente un dogma tradicional, sino que se basa probablemente en la convicción - que el autor del presente trabajo considera justificada - de que un Jurado británico es muy raras veces hostil al acusado y trata en conciencia de preservar las salvaguardias que la ley de Inglaterra concede generosamente, quizás demasiado generosamente, $\alpha$ la person $\alpha$ acusada. En este sentido, el Jurado tiene todavía derecho a ser considerado como una institución auténticamente protectora de la libertad.

\section{El orden público}

Ante la ley, todo ciudadano británico tiene el deber de preservar el orden público. En Inglaterra, el concepto de orden público se formuló por primera vez en tiempos de los anglosajones $y$ se ha perfilado tras muchos cambios. $A$ lo largo de muchos siglos y mediante diversos procedimientos que no pueden ser descritos aquí, Inglaterra tható de que la comunidad velara por su propia seguridad. Ninguno de los métodos empleados alcanzó un éxito completo y, como resultado, durante la mayor parte de su historia, Inglaterra, que constantemente proclama con orgullo su convicción de ser una "nación respetuosa de la ley", fue en realidad un país en el que reinaba la mayor inseguridad pública. $\bar{A}$ principios del siglo XIX, Inglaterra era en. Europa el país que peor renombre tenía por lo que se refiere a los delitos. graves o leves, cometidos en él. No por ello era menor la fuerte oposición con que se combatía la propuesta creación de una policía profesional permanente, porque on general la opinión pública ingles $\alpha$ estaba convencida de que tal institución sería un instrumento de opresión gubernamental. No fue sino en 1829 cuando sir Robert Peel, desafiando la opinión pública. estableció ja primera Policía Metropolitana, ejemplo que fue imitado pronto en el resto del país. Pasaron muchos años antes de que los "Bobbies" (denominación popular de los policías), bajo la sabia y paciente dirección de los 
primeras comisarios generales, Rowan Y Mayne, consiguieran vencer el prejuicio popular. Hoy día tal antagonismo ha desaparecido. Es indiscutible que la policía británica goza del apoyo y aprobación de todos los súbditos do buenas intenciones y recibe también el respeto, expresado a regañadientes, de los delincuentes. Al modo de ver del autor de estas líneas, es también. claro que la creación de una policía honrada y eficiente, junto con la mejora de las condiciones sociales, ha contribuído de manera muy marcada a fomentar el respeto por la ley. Por desgracia, desde el final de la segunda guerra mundial, los delitos graves han aumentado en Inglaterra $a$ un ritmo causante de gran preocupación, aunque la situación general en lo relativo a la ley $y$ el orden dista mucho de ser la existente hace 150 o incluso 100 afios.

Ha sido siempre un principio fundomental del derecho inglés que el policía es en primer lugar un ciudadano. No es un funcionario de la Corona: La institución en la que presta sus servicios no estó organizada a escala nacional, sino que cada condado rural o urbano dirige su propio contingente, sujeto a ciertas facultades de coordinación. de alcance limitado, que posee el Ministro del Interior. A pesar de que actualmente le incumbe de manera principal descubrir $Y$ perseguir a los delincuentes, el agente de policía tiene facultades cuya competencia no es mucho mayor que la del ciudadano corriente. En cierta medida, el ciudadano es un agente de policía. En teoŕa, tiene la obligación, bajo pena de incurrir en el delito de encubrimiento, de no ocultar ningún delito grave cuya comisión conozca (11), nl mucho menos puedo consentir que se ejecute. A pesar de que sería excesivo decir que el ciudadano tiene la obligación de oponerse a cualquiera que intente perturbar el orden público, comete un delito si no presta asistencia $\alpha$ un agente del orden público, cuando se le requiera a ello. Assimismo, la policía regular (cuyos efectivos actuales en Inglaterra y Cales se elevan a 69,000 agentes) está ayudada por un cuerpo bastante numeroso de policías especiales voluntarios, $\alpha$ los que puede movilizarse en ocasiones determinadas o cuando se declara el estado de urgencia. Estos agentes prestan servicios sin recibir remuneración alguna $\mathrm{y}$ dedica una parte considerable de su tiempo a realizar prácticas de servicios elementales de policía. Proceden de todas las clases sociales. En breves palabras, es principlo del derecho inglés que todos los súbditos tienen la obligación respectó del Soberano de preservar la seguidad del Reino, que es el símbolo del buen orden general de la comunidad.

En la actitud del público hacia la policía se observan dos notas características, aparentemente contradictorias. Por una parte, el "Bobby" es una gloria nacional, lo que se expresa a veces con un grado exagerado de satisfacción. Por otra parte, nada provoca una protesta más repentina y apasionada que cualquier abuso o exceso de las facultades de la policía o el empleo de métodos considerados como "ṇo deportivos"; parece que una

11. Sin embargo, los procesamientos por aste delito han caido totalmente en desuso

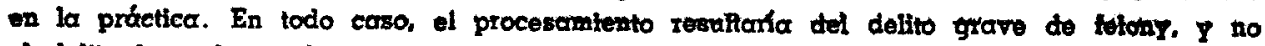
el delito leve de misdemeanor entre los cuales la ley inglese establece una distinción sumamente técnica. 
de las normas fundamentales de una nación que ama los juegos sujetos a reglas es dar al delincuente una oportunidad en su lucha con sus conciudadanos respetables. Por tanto, el policía debe actuar siempre con mucho tiento. Por ejemplo, on toda actuación que le ponga en contacto con un acusado o sospechoso, el policía tiene que ajustarse a un código, actual: mente muy extenso $y$ complicado, que tiene por nombre Reglamento de los Jueces (Judges Rules). Este código tiene por objeto establecer salvaguardias contra la obtención de admisiones o confesiones por medio de procedimientos indebidos de persuasión o engaño. Interpretado con estrecho rigor, no hay duda de que el código dificulta la labor del policía, pero sus preceptos se observan en general y es un hecho que goza de la aprobación del público. En resumen, el pueblo británico, que se enorgullece de sus mantenedores del orden público, hace gala de estar firmemente decidido a custodere custodes.

\section{Los lueces de par}

Inferiores en grado a los magistrados, están los funcionarios encargados por el soberano de mantener el orden público y cuyo deber básicó queda indicado por su nombre de jueces de paz. Fueron creados probablemente en el siglo XIV, tal vez antes, y la ley de 1361 que les confirió sus facultades $Y$ deberes generales esta todavía en vigor $y$ es invocada de vez en cuando. Los jueces de paz son nombrados por la Reina por recomendación del Lord Canciller, a quien prestan asistencia a título confidencial comités asesores locales designados por él. Al contrario de los magistrados del Tribunal Supremo, pueden ser separados de su cargo según el arbitrio del soberano, aungue de hecho es muy raro que se aplique esta medida disciplinaria. Salvo en circunstancias excepcionales, el tribunal de un juez de paz (petty sessions) debe estar compuesto por un número de miembros que puede variar entre un mínimo de dos $y$ un móximo de siete; funciona bajo la dirección de un presidente elegido por los miembros. Los jueces de paz no perciben remuneración alguna. En su mayoría, son ciudadanos que no han recibido formación jurídica. Si bien antes procedían generalmente de la clase de los propietarios, en especial de la hidalguía rural, hoy se trata de asegurar que los jueces de paz representen a los diversos sectores sociales. El límite superior de edad se ha fijado en los 75 años; en 65, en los casos de los tribunales de menores. En la actualidad, hay unos 17,000 jueces de paz, que dirigen en todo el país alredeaor de un millar de tribunales que funcionan durante los periodos de sesiones (petty sessional divisions) que determina la ley. En los condados, los tribunales funcionan no sólo en los períados de sesiones mencionados, sino también en períodos de sesiones trimestrales (Quarter Sessions) en los que los juicios son por jurados, bajo la dirección de un presidente que en la actualidad es casi siempre un abogado (barrister) o un magistrado de tribunal de condado o del Supremo. En los condados urbanos en los que hay un funcionario especial encargado de mantener el orden público, los jueces de paz sólo fallan los casos que se presentan a los tribunales de petty senaions. En tales lugares, los juicios de Quarter Sesslons co- 
rren a cargo de un Recorder (que es un abogado de renombre, designado por el Lord Canciller) con un jurado. (12).

Durante siglos, los jueces de paz desempeñaron funciones en la esfera administrativa que eran fasi más importantes que las ejercidas en la judicial. En su calidad de jueces, fallaban los casos sometidos a los tribunales trimestrales (como todavía sucede en los condados rurales), pero en la mayoría de los casos los jueces de paz eran también los gobernantes de las regiones rurales del país, en las que desempeñaban una gran variedad de deberes administrativos o de supervisión. Sus facultades han dimanado siempre del derecho estatutario, no del derecho común, y el Parlamento amplió gradual y progresivamente su jurisdicción hasta facultarles para entender de ciertos delitos de menor cuantía "fuera de sesiones", esto es, en su propio tribunal, o sea sin tener que reunir un Jurado. Mientras la competencia de esta juriselicción sumaria -como se la llama actualmente- aumentaba de modo gradual, las funciones de los jueces de paz en materia de administración local quedaban más y más desbordadas por el crecimiento de la población y la formación de grandes concentraciones urbanas durante la era de la industrialización. Como culminación de un largo proceso, la Ley de 1888 estableció en Inglaterra las bases del actual régimen de administración local y privó de un golpe a los jueces de paz de sus atribuciones administrativas más importantes. Sin embargo, la ley había seguido acrecentando sus facultades en la esfera de la jurisdicción penal sumaria. En consecuencia, las actuales funciones administrativas de los jueces de paz - principalmente la legalización de documentos, declaraciones $\mathrm{y}$ certificados- son de menor importancia, mientras que sus atribuciones judiciales han aumentado enormemente y parecen multiplicarse de manera constante.

Se trata ciertamente de una jurisdicción extensa y variada. Además de los delitos y faltas, su competencia abarca materias tales como la delincuencia juvenil, la adopción, la bastardía, la tutela de los niños de corta edad. la autorización de la venta de bebidas alcohólicas y otras autorizaciones, algunos aspectos de la demencia y de la deficiencia mental, y los pleitos matrimoniales. En esta última esfera, importante y difícil, los jueces tienen limitadas sus atribuciones a la consideración de las quejas sometidas por esposas, pero sus facultades son casi tan importantes como las del Tribunal Supremo. Por ejemplo, al aplicar la "cláusula de no cohabitación", pueden dictar lo que en realidad equivale a una separación judicial y pueden determinar también quién va sostener $y$ custodiar a los hijos, pero no tienen, como es natural, autoridad para decretar la disolución efectiva del vínculo matrimonial.

Por razones de espacio, es evidentemente imposible examinar aquí todas las especialidades de esta jurisdicción y otros muchos deberes de gran variedad que incumben a los jueces de paz. Por ello, nos limitaremos

12. Algunos condados, rurales o urbanos, tienen un funcionario especial encargado de mantener el orden público no porque así lo disponga una norma tija o estatutaria. sino por razones de orden histórico, por costumbre o en virtud de una carta real. 
a la parte más extensa de la jurisdicción de los jueces de paz que es la relativa a la esfera penal.

Conviene distinguir, desde un principio, entre dos clases de delitos según los divide la ley inglesa: los que deben ser examinados por un magistrado $y$ por jurados (o por una sala de magistrados en los tribunaies trimestrales) y los que pertenecen a la esfera de la jurisdicción sumaria, o sea los que pueden llegar a una conclusión bajo la dirección de magistrados que actúan como jueces de hecho y de derecho y que están facultados para imponer una pena. Toda acusación de índole penal es examinada en primera instancia por magistrados (13). Algunos de los hechos punibles más graves, entre ellos los delitos de asesinato, homicidio, rapto, robo, robo con escalamiento y escalo, no pueden ser juzgados por los tribunales de petty sessions. Sin embargo, incumbe a los magistrados que examinan las pruebas cometidas por la acusación levantar un acta literal de las declaraciones presentadas por escrito $y$ decidir si hay lugar prima facie para remitir al acusado, como posible reo de delito, ante un Jurado. De hacerse así, el caso se eleva a un tribunal superior (Assizes - Quarter Sessjons) para un juicio por jurados. En caso contrario, el acusado es declarado inocente en el acto. En el desempeño de estas funciones, los jueces de paz reciben el calificativo de magistrados de instrucción, y nadie puede ser procesado ante un Jurado si no se ha practicado la encuesta preliminar que se ha descrito y en la cual el acusado goza de plenos derechos para defenderse, repreguntar y convocar a testigos.

Otra categoría, mucho más vasta, de hechos punibles -entre ellos el más común de todos, el de hurto- pueden ser sancionados por magistrados, pero sólo si el acusado da su consentimiento para esta clase de juicio. El acusado puede optar entre el juicio sumario $y$ el juicio por jurados; si elige la segunda jurisdicción, el procedimiento reviste la forma de instrucción y deposiciones, distinto del juicio descrito. Los casos en que el acusado de hecho punible tiene el derecho de opción estón especificados en el derecho estatutario; además, el reo tiene la misma facultad cuando ha sido acusado de un delito por el que incurre en una pena de privación de libertad de más de tres meses de duración. Es obligación estricta del tribunal informar al acusado de la posibilidad de escoger entre las dos jurisdicciones y cerciorarse de que ha comprendido cuál es su situación.

Por último, en el caso de muchas faltas, muy diversas, de "jurisdicción sumaria", no se tiene derecho a pedir el juicio por jurados y son los jueces de paz los encargados de oírlas y juzgarlas. Se trata principalmente de faltas leves que en el derecho trancés reciben el nombre de contraventions, muchas de las cuales son actualmente infracciones de los reglamentos de tránsito por carretera.

Con muy pocas excepciones, las atribuciones de los jueces de paz para sancionar se limitan a la imposición de una multa de cien libras esterlinas o seis meses de arresto por un solo delito o bien, en el caso de un reo convicto de varios delitos, doce meses de arresto como máximo. Ocurre $\alpha$ veces que un acusado escoge el procedimiento sumario para

13. Excepto, como antes se ha dicho, por auto dictado por un coroner. 
ser juzgado por un hecho que, a primera vista, no es un delito grave, pero si el acusado queda convicto o se declara culpable, el tribunal recibe un informe sobre sus antecedentes y puede descubrirse entonces que se trata de un criminal endurecido, con un largo historial penal. En tal caso, los magistrados están facultados por una ley reciente (14) para remitir el caso, sólo para sentencia, a un tribunal de sesiones trimestrales que tiene atribuciones mucho más vastas en materia de penas que los tribunales de "petty sessions". Debe advertirse al acusado de esta posibilidad antes de que escoja entre la jurisdicción sumcria o de Jurado.

Puede apelarse contra cualquier sentencia condenatoria dictada por los jueces de paz ante los tribunales de sesiones trimestrales por cuestiones de derecho o de hecho o por lo excesivo de la sentencia, o por los tres motives a la ven, y el juicio de apelación es una revisión completa del caso. En lo relativo a una cuestión de derecho, puede apelarse ante la "Queen's Bench Division" por declaración de los magistrados (si éstos creen que se ha planteado un punto de derecho que se puede argüir). Tanto la acusación camo la defensa pueden utilizar este recurso de apelación contra una sentencia absolutoria. Sin embargo, su alcance es limitado, ya que si la acusación demuestra estar jurídicamente en lo cierto, la cuestión no queda resuelta de manera definitiva. El caso es devuelto a los magistrados con instrucciones para que "declaren convicto al reo", pero se deja enteramente a su arbitrio imponer la pena. Por lo común, las conclusiones de los magistrados sobre las cuestiones de hecho son aceptadas por la "Queen's Bench", pero es posible que esta sala juzgue que, como cuestión de derecho, las conclusiones están viciadas por estar en pugna con el resultado de las pruebas y no bastan por consiguiente para que se base sobre ellas una convicción. Ello ocurre varias veces, y no es permisible en el caso de una absolución. Además de los procedimientos de apelación mencionados, todos los tribunales de magistrados están sujetos a los mandamientos de prerrogativa de la "Queen's Bench":mandamus, prohibición y certiorari. No es posible describirlos aquí en detalle, pero como ejemplo, el más trecuente, de esta clase de recursos diremos que, cuando los jueces de paz se han equivocado o excedido su jurisdicción, su decisión puede ser anulada por un mandamiento de certiorari, lo que implica el fin de la cuestión, ya que en esta instancia el tribunal no tiene atribuciones para dictar sentencia o para remitir de nuevo el caso a los magistrados, ni siquiera si las pruebas han demostrado claramente la culpabilidad del acusado.

Si se suman los delitos de jurisdicción primaria propiamente dichos $y$ los delitos en los que è acusado, al ser juzgado, escoge el juicio sumario, se ve que en Inglaterra en un 95 por ciento $y$ hasta en un 98 por ciento de los casos las acusaciones criminales son oídas y decididas por magistrados no remunerados y legos en su mayoría; por tanto, sólo un 2 ó 3 por ciento de las acusaciones criminales son juzgadas por un magistrado con jurados. Sí, por otra parte, se deducen los procesos vistos ante los tribunales superiores en los que el acusado se reconoce culpable, la proporción

14.-Criminal Justice Act. 1948, s. 29 (Loy de Justicia Criminal). 
de casos en que es preciso reunir un Jurado es probablemente inferior al uno por ciento.

A juicio de los extranjeros interesados por el tema, este sistema es sorprendente. Se preguntan cómo es posible que hombres y mujeres carentes de formación jurídica, procedentes de distintos medios sociales $y$ diferenciados por su propia experiencia, sean jueces satisfactorios no sólo de los hechos, sino támbién de derecho penal. Es un error que se comete a menudo suponer que un magistrado sólo necesita "sentido común". Necesita, claro está, poseer esta cualidad, unida a una visión judicial desprovista de prejuicios, capaz de evaluar los hechos y los puntos de derecho, algunos de los cuales, difíciles y todavía no resueltos, se plantean constantemente. Entre los muchos tratados voluminosos de derecho judicial en uso, el más corriente es el "Justices' Mrnual" por Stone (ya en su $89^{\circ}$ edición), que ocupa una extensión de más de tres mil páginas de letra menuda y cita millares de disposiciones legales y de sentencias

En su actuación, un magistrado inteligente y consciente de sus deberes aprende, como es natural, muchos de los preceptos legales que deberá aplicar. En todo lo demás, los jueces se sirven de los consejos de los secretarios de la magistratura, que tienen la calidad de letrado y que por lo común reúnen las condiciones necesarias para ejercer de solicitor (procurador) 0 , menos corrientemente, de barrister (abogado). En la administración de justicia, estas funcionarios desempeñan un papel de la mayor importancia. Deben poseer, junto con una memoria fácil, vastos conocimientos sobre todas las divisiones de las diversas jurisdiceiones y del procedimiento $y$ deben estar prontos en todo momento a prestar asistencia a los jueces sin dar la impresión de que se sobreponen al tribunal. Deben ser administradores y abogados al mismo tiempo, ya que les incumben muchas responsabilidades financieras y de gestión de negociado y dirigen un personal cuyos efectivos varian, según el númera de asuntos que se ventilan en cada tribunal, desde dos a tres empleados en los distritos rurales hasta veinte o treinta en las ciudades. En general, su nivel de competencia es elevado y sus sueldos son más bien generosos, conforme a lo establecido en una escala nacional. Teniendo en cuenta el número de cuestiones respecto de las cuales prestan constantemente asesoramiento a los magistrados y lo diverso de sus responsabilidades administrativas, el número de equivocaciones que cometen es pequeño. El público les conoce poco y no gozan de una elevada consideración profesional. En la organización judicial, los secretarios - cuya misión es quedarse "entre bastidores"- ocupan un lugar vasto y de gran importancia.

En buena parte, los jueces de paz realizan una labor de carácter más bien social y humanitario que juridico. Cada tribunal tiene adscrito un Probation Officer, funcionario (masculino o femenino) de asistencia social (varios en los distritos más populosos), cuyo cometido es, haciendo uso de su ascendencia, ofreciendo sus consejos o imponiendo normas de disciplina, tratar de redimir al delincuente $y$ evitar que caiga en la delincuencia habitual. Es norma general de los tribunales de los jueces de paz no imponer penas si un período de prueba puede producir resultados positivos, en especial si se trata de delincuentes jóvenes o de delincuentes por pri- 
mera vez. Por lo demás, una ley reciente (15) prohibe que se prive de libertad a ninguna persona cuya edad sea inferior a los 21 años, salvo en circunstancias excepcionales. Los funcionarios de asistencia social, que han seguido los cursos organizados por el Ministerio del Interior, deben ser - Y ésta es la realidad en la mayoría de los casos- personas impulsadas por el sentido de cumplir una misión social. Lo mismo se aplica a muchos jueces, que realizan voluntariamente una variada labor social y que a menudo han sido nombrados porque han evidenciado ser ciudadanos dotados de un gran espíritu público.

El delincuente sometido a prueba no se ha salvado "por las buenas". Tiene que cumplir con las obligaciones que se le han impuesto, entre las que figuran guardar buena conducta general y observar asiduidad en el trabajo y, a veces, cumplir las obligaciones especiales exigidas en un caso particular. Si no las cumple, el funcionario de asistencia social puede informar al tribunal para que éste sancione al delincuente o le amoneste según convenga. Si comete otro delito durante el período de prueba (uno, dos - tres años), el delincuente puede ser sancionado por el nuevo delito $y$ por el perpetrado originalmente. Algo parecido es el procedimiento deI "perdón condicional", que consiste en dejar por el momento impune al acusado y hacerle reo de dos delitos en el caso de que cometa un segundo delito dentro de un plazo que se especifica y que es por lo común de doce meses. En su mayor parte, la opinión pública britónica parece preferir estos métodos a la "suspensión de la sentencia", que es el procedimiento utilizado por muchos países.

Al imponer penas pecuniarias, los magistrados deben tener presentes los medios de vida del acusado y darle, si ello parece conveniente, un plazo razonable durante el cual pueda pagar la multa impuesta. El principio de que la pena debe ser proporcional al delito y tener también en cuenta la personalidad del delincuente está muy arraigado y a menudo un tribunal aplaza su sentencia hasta después de haber recibido un informe sobre el delincuente preparado por un funcionario de asistencia social o un médico o por ambos. Ásimismo, en casos apropiados los tribunales tienen atribuciones, que emplean a menudo, para facilitar al acusado medios de defensa legal.

El Tribunal de Menores está formado por jueces especializados $Y$ funciona bajo la dirección de un presidente elegido por los mismos jueces. Los acusados menores de 17 años son juzgados por este Tribunal (16), el cual tiene atribuciones para imponer multas (a veces asigna a los padres la obligación de hacerlas efectivas), colocar en período de prueba, retener al acusado en uno de los reformatorios (Approved Schools) del Mi-

15.-Criminal Justice Act. 1948, s, 17 (Ley de Justicia Criminal).

(16) A no ser que el menor comparezca en compañía de adultos ante un tribunal ordinario, en cuyo caso, de ser declarado culpable, puede ser transferido al Tribunal de Menores paraque éste tome una decisión a su respecto. 
nisterio del Interior $y$, en el caso de que el menor se halle "necesitado de cuidados y de protección", "en desobediencia". o, en el caso de una muchacha, "en peligro moral", ponerla bajo la autoridad de una entidad de administración local. La competencia de este Tribunal abarca también la adopción. En el caso de cometer un delito o de perpetrarlos con frecuencia, los delincuentes que tienen entre 17 y 21 años pueden ser retenidos en las instituciones de reforma Borstal por decisión de los tribunales de sesiones trimestrales por recomendación de los magistrados, si los Comisarios de Prisión certifican que seráa apropiado al caso este tratamiento que tiene el carácter de "formación" más bien que de castigo. Salvo en el caso posible de liberación otorgada por autorización especial, la retención dura corrientemente tres años.

Hasta ahora nos hemos referido a los jueces legos, que a menudo reciben el remoquete de los "personajes que no cobran". Sin embargo, hay otros magistrados llamados estipendiarios, que tienen la calidad de letrado, son funcionarios permanentes $y$ fallan en tribunales unipersonales. De esta clase hay actualmente en Londres 26 jueces, a los que se da el nombre de magistrados metropolitanos: en las provincias, hay otros 14 . Los condados rurales $y$ urbanos pueden pedir que se nombre para su demarcación un magistrado estipendiario permanente, pero no parece que exista una corriente popular favorable, excepto en los centros urbanos donde las actividades judiciales. son difíciles y continuas. Los estipendiarios tienen las mismas atribuciones y obligaciones que los demás magistrados $y$, trente $\alpha$ sus decisiones, puede apelarse de la forma ya expuesta. Su remuneración equivale casi a la percibida por los magistrados de tribunales de condado y casi todos han ejercido la abogacía antes de ser nombrados.

¿Qué opinión tiene el público británico en general acerca de un sistema de organización judicial administrado por los mismos ciudadanos? EI juez inglés (Peak, o "pico", como se le llama popularmente) es objeto cons. tante de críticas $y$, como el "Bobby", es blanco favorito de la sátira y la parodia. No obstante, esta actitud no es muy reveladora, ya que el pueblo británico tiene por costumbre mofarse de todas las instituciones por las que siente mayor estima. El punto más débil del sistema reside en el hecho de que, dada la multiplicidad de tribunales, es díficil que su eficiencia, funcionamiento o métodos punitivos sean uniformes, lo que con frecuencia provoca comentarios, no siempre injustificados. Sin embargo, esta disparidad parece ser inevitable cuando muchos tribunales penales funcionan simultáneamente, y si la afirmación es cierta respecto de los jueces de paz, también lo es con relación a los jurados e incluso a los magistrados. $\mathrm{De}$ vez en cuando se promueve una campaña en favor del nombramiento de estipendiarios permanentes, pero, aparte de que sería imposible designar el número suficiente de profesinnales preparados, parece significativo que las muchas entidades locales que tienen derecho a pedirlo (como queda explicado) no tengan la intención de hacerlo. Las posibilidades de apelar contra las decisiones de los jueces de paz son muy amplias $y$, por supuesto, ocurre a veces que los jueces cometan errores de derecho o de hecho. Con todo, el número de apelaciones es ínfimo frente al total de decisiones. Como se dice antes, la inmensa mayoría de los acusados de hechos punibles escoge, cuando la ley 
lo permite, el juicio por magistrados y no por jurados, y aunque pudo decirse antes que ello ocurría porque los poderes punitivos de los jueces son limitados, esta opinión no se ajusta ya a la realidad desde que es posiblo remitir la persona declarada culpable $\alpha$ un tribunal superior para que éste dicte la sentencia apropiada. Habida cuenta de la suspicacia que muchos profanos sienten por la vida jurídica, es opinión generalizada que los tribunales de jurisdicción sumaria están rodeados por la confianza del público y que pocos acusados estiman haber sido tratados inequitativa o injustamente por la acusación y por el tribunal. Es probable, por otra parte, que la difusión extensa de las funciones judiciales entre los ciudadanos, que consideran su designación como el reconocimiento de sus méritos y reputación cívica, contribuya a hacer más amplio el respeto por la ley $\mathrm{y}$ el orden, Y puede afirmarse sin reservas que la gran mayoría de los jueces toma sus deberes con sentido de responsabilidad y hacen cuanto está de su alcance para administrar justicia en conciencia y de manera humanitaria, $\alpha$ menudo a considerable costa de su tiempo, su propia comodidad y hasta su bolsillo. Como muchas instituciones británicas, la "justicia lega" es fruto del desenvolvimiento histórico y su concepción es tan poco científica que, en teoría, su funcionamiento es inexplicable, aunque de hecho consiga funcionar con un sorprendente grado de éxito.

\section{Otros tribunales}

Hay otra esfera en la que muchos ciudadanos ejercen en la actualidad funciones que pueden ser calificadas de judiciales. En Inglaterra, como en la mayoría de los Estados Modernos, el Gobierno y la Administración han adquirido más y más una gran complejidad bajo la influencia de una teoría política de tendencia socializante, y este proceso se ha agudizado todavía más debido a la gran ampliación de los servicios estatales por efecto de las necesidades de la guerra y la postguerra. Como resultado de tal estado de cosas, se han creado muchos tribunales anexos a la Administración pública, la mayoría de ellos por decisión legislativa; otros han sido establecidos de modo espontáneo, principalmente en la industria y el comercio. Muchos son competentes en materia de servicios sociales: sanidad nacional, seguridad $\mathrm{y}$ asistencia social, prestaciones familiares; otros ejercen funciones de supervisión, que es actualmente muy estricta en Inglaterra, sobre la tierra, la vivienda, la planificación rural y urbana y la agricultura; hay otros que se ocupan de cuestiones relativas al transporte, al servicio militar, las pensiones de guerra $Y$ las industrias nacionalizadas. En toda la industria funcionan innumerables tribunales y juntas de arbitraje; casi todas las profesiones liberales tienen tribunales disciplinarios propios, y algunos de ellos (por ejemplo, la medicina y la abogacía) tienen vastas atribuciones punitivas respecto de sus miembros. En diversas industrias de producción agrícola primaria, Juntas de Comercialización, de características muy variadas, tienen atribuídas facultades similares. Análogos a estos tribunales, aunque sin tener atribuciones judiciales, funcionan muchos comités asesores que se han creado para prestar asistencia a casi todos los Departamentos de la Adminitración pública. 
Los organismos con poder para adjudicar han sido establecidos de manera rápida e inconexa, lo que ha tenido por resultado una falta total de homogeneidad. Hace poco tiempo, la Comisión para el estudio de los Tribunales y Encuestas de Carácter Administrativo (a la que se da por lo común el nombre de Comisión Franks, que es el de su presidente, sir Oliver Franks) recogió un vasto caudal de informaciones relativas a varias clases de tribunales creados por decisión estatutaria. El informe de la Comisión, publicado en 1957 (Cmnd. 218), es un documento constitucional de la mayor importancia, aunque, debido desafortunadamente a los límites señalados a las atribuciones de la Comisión, abarca sólo un sector de un campo muy vasto que está en proceso de crecimiento continuo. La Comisión formuló muchas recomendaciones, muchas de las cuales el Gobierno ha hecho suyas y que están siendo ahora objeto de medidas legislativas que las pondrán en marcha. En general, las recomendaciones formuladas tienden a revisar las atribuciones y los procedimientos de estos diversos "organismos de adjudicacjón" con vistas a una mayor uniformidad, garantía procesal y publicidad, y también con el objeto de establecer medios de apelación más amplios ante tribunales superiores 0 ante los ordinarios en todas las materias que se refieran a la libertad y a los derechos de propiedad de los súbditos. Estas cuestiones administrativas revisten demasiada amplitud para que sea posible tratalas aquí, pero uno de los hechos más saltantes que la encuesta puso de relieve es el número sorprendentemente elevado de ciudadanos que, en el terreno administrativo, desempeñan lo que en realidad son funciones judiciales.

Casi todos los tribunales más importantes, cuyos miembros son designados por el Lord Canciller o por los Ministerios, funcionan bajo la dirección de un presidente que tiene la calidad de letrado y algunos, tales como el Comisionado de Seguros, el Tribunal de Transportes y el Tribunal de Tierras, casi se confunden con los tribunales de justicia ordinarios. Sin embargo, la mayoría de los miembros son legos, algunos de ellos perciben honorarios según taritas muy modestas y muchos otros no reciben remuneración alguna a excepción del reembolso de sus gastos. Los miembros de un tribunal son escogidos en vista de su acreditada nombradía de ciudadanos conscientes de sus deberes $\theta$ imbuídos del espíritu de servicio a la comunidad, o bien habida cuenta de su experiencia y conocimientos especializados en determinadas esferas. La Comisión Franks puso de relieve un principio que había sido olvidado algunas veces por jueces de mentalidad burocrática - a saber, que los miembros de los tribunales administrativos no son meros apéndices del poder ejecutivo, sino que son personas encargadas de dictar fallos cuyas consecuencias afectan de manera principal los derechos y los deberes de los ciudadanos. La Comisión recomendó que, normalmente, los tribunales fueran dirigidos por un presidente letrado; pero, tal como ocurre con los magistrados, no hay razón para sospechar que los miembros legos de un tribunal administrativo (preferentemente, si actúan siguiendo las orientaciones del presidente, como se expone más adelante) carecen de la mentalidad judicial necesaria para decidir las cuestiones que se les someten.

En la actualidad, no se dispone de cifras exactas relativas al núme- 
Io total de los miembros de estos tribunales, pero autoridades en la materia calculan que debe oscilar entre quince $y$ veinte mil. Por consiguiente, si sumamos las cifras de los jueces de paz y de los "árbitros" administrativos (muchas personas desempeñan ambas funciones), se llega a la conclusión de que, en una población de unos cincuenta millones de habitantes, entre treinta y cuarenta mil miembros del público estón encargados de manera permanente de tomar decisiones relativas a los derechos y responsabilidades de sus conciudadanos, además de los muchos funcionarios forenses profesionales. El autor del presente trabajo no sabo si las cifras mencionadas son superiores 0 inferiores a las correspondientes a otros países, pero se cree generalmente que sería difícil hallar en otro país una situación análoga a esta amplia distribución de lo que puede denominarse responsabilidades cívico-judiciales. En conjunto los tribunales funcionan de modo eficiente e imparcial y a satisfacción del público, cuanto más porque generalmente son menos lentos y ciertamente menos caros que los tribunales ordinarios. Su principal punto débil es que han crecido y aumentado al azar, y ello ha entrañado diversidades no sistemáticas en lo relativo a sus constituciones, facultades y procedimientos. Sin embargo, tal como queda expuesto, se estón examinando estos defectos y existen perspectivas de forma gradual; en Inglaterra, toda reforma es gradual $y$, en realidad, su necesidad es un hecho generalmente aceptado desde tiempo atrás.

\section{La mujer y la ley}

En 1919, tras enconadas controversias y mucho escándalo público, la Ley para eliminar las inhabilitaciones fundadas en diferencias de sexo equiparó a la mujer con el hombre en la mayoría de los asuntos cívicos, haciendo posible, entre otras cosas, que participara en la administración de justicia. Dado que, en teoría, el nombramiento de los jueces de paz es una de las prerrogativas reales, nunca había habido ningún impedimento que hiciera imposible el acceso de las mujeres a la carrera judicial, aunque de hecho ello habia ocurrido en muy raras ocasiones. Sin embargo, después de 1919, tales nombramientos son corrientes $y$ en la actualidad una cuarta parte de los jueces de paz son mujeres. No pocas son elegidas presidentes: de tribunal $\mathrm{Y}$ una ocupa permanentemente el cargo de magistrado metropolitano, en Londres.

También se reconoció a la mujer su elegibilidad como jurado, aunque su número está restringido porque, como ya se ha visto, los jurados deben ser propietarios o poseer domicilio propio, lo que excluye a la mayoría de las mujeres casadas. Además, en ciertas circunstancias puedo convocarse un Jurado compuesto únicamente por hombres $y$, en todo caso, la proporción de mujeres en un Jurado no debe rebasar la que existe $\mathrm{m}$ el registro electoral. En consecuencia, en un juicio penal un Jurado de doce raramente tiene entre sus miembros a más de una o dos mujeres.

Se suscitaron mucha sorpresa y críticas cuando, durante la guerra de 1914 a 1918, un número limitado de mujeres-policía entró a prestar servicio, a título experimental, en la zona metropolitana. Probaron su utilidad y eficiencia de modo tan cumplido que se extendió la práctica gradual- 
mente en todo el pais y en la actualidad el número total de policías femeninos de plantilla se eleva a alrededor de 2.000. A juicio casi unánimo del público, las mujeres-policía han justificado plenamente su existencia, en especial para ocuparse de los delincuentes juveniles y femeninos, y algunas de ellas han sido objeto de grandes elogios por el valor demostrado en la ejecución de sus deberes.

Muchos hombres acarician la idea, quizás sea mera superstición, de que la mujer es demasiado sentimental o ilógica para tener la "mentalidad jurídica". Este punto de vista no queda corroborado en lo más mínimo por la experiencia judicial o policíaca inglesa. No hay duda de que el elemento femenino ha enriquecido de manera útil la justicia sumaria $y$ de hecho ha demostrado tan cabalmente su eficacia que la ley exige ahora que la mujer participe en dos divisiones de dicha jurisdicción, la matrimonial $Y$ la juvenil, en las que su función es particularmente apropiada. No hay tampoco fundamento para el temor, expresado años atrás, de que determinados casos no son adecuados para oídos femeninos. Los tribunales de derecho, en especial los de derecho penal, tienen que ocuparse a menudo de cuestiones poco delicadas y de anormalidades morbosas. Sin embargo, la experiencia enseña que la mujer no rehuye más que el hombre el desempeño de estas tareas desagradables y que puede ser en esta materia tan realista y desapasionada como él. Por otra parte, en las actividades sociales colaterales a que se ha aludido, encaminadas especialmente a prestar asistencia a los delincuentes y a facilitar su readaptación, muchas mujeres-magistrado se muestran sumamente activas. Cualquier propuesta cuyo objeto fuera hoy día declarar incompetente a la mujer inglesa para desempeñar funciones judiciales sería condenada por todos, como hace cincuenta años se resistía con violencia contra su nombramiento.

\section{Conclusión}

Hay otros casos en los que el ciudadano corriente puede desempeñar un papel asesor, como consejero, en los trabajos judiciales. Así, ante la sala de "Admiralty", en acciones por daños o salvamento de buques, el juez actúa acompañado por peritos náuticos, los llamados Trinity Masters; sin embargo, si las partes asi lo acuerdan, como ocurre a menudo, su presencia no es necesaria. En otras acciones ante la misma sala, puede convocarse a peritos, bien a petición de las partes o por orden del juez, aunque pocas veces se utilizan los servicios de los peritos. Su función es asesorar sobre cuestiones técnicas relativas a la navegación y prácticas marineras, pero no tienen facultades para decidir una cuestión de derecho o de hecho; esta responsabilidad sólo incumbe al juez, que, como ya se ha dicho, actúa sin Jurado. Por otra parte, si se emplean los servicios de los peritos, su asesoramiento sobre cuestiones técnicas excluye la convocatoria de expertos testigos por las partes en la acción.

A fin de prestar asistencia a los tribunales de otras jurisdicciones (Tribunal de Apelación, Tribunal de Apelación Criminal, tribunales de condado), puede convocarse a asesores en materias especializadas. Lo mismo se aplica a determinados procesos eclesiásticos de carácter disciplinario 
(sólo los clérigos reúnen las condiciones necesarias en este caso). En virtud de determinadas disposiciones legislativas (17), el Tribunal Supremo puede hacer uso de una facultad de carácter general que lo cutoriza a emplear los servicios de asesores en las circunstancias apropiadas. Sin embargo, a excepción de la sala de "Admiralty", estas disposiciones tienen poca importancia práctica. Así, en los cincuenta años de existencia del Tribunal de Apelación Penal, jamás se ha aplicado la sección 9 (e) de la Ley de Apelación Penal de 1907, que faculta al tribunal para convocar a una persona "dotada de conocimientus especiales", mientras que en el tribunal de Apelación no parece que se convoque nunca a asesores y en los tribunales de condado su existencia es virtualmente desconocida.

En todo caso, las personas dotadas de calificaciones en cuestiones técnicas no son propiamente representativas del público lego general $y$. en la mayoría de las ocasiones, su actuación en el sistema juridico inglés reviste la forma de servir como testigos, en epecial como expertos médicos - calígrafos. Debe confesarse que, como resultado de las acusadas diferencias de opinión que a veces las separan, we han ganado una reputación en manera alguna envidiable.

La Ley de 1956 que creó el Tribunal de Prácticas Comerciales Restrictivas constituye una iniciativa de gran interés. En virtud de dicha Ley, la Reina, por recomendación del Lord Canciller, puede nombrar como miembros del Tribunal, además de los magistrados del Tribunal Supremo, a personas que estén considéradas como particularmente aptas para el cargo por razón de "sus conocimientos o experiencia en materia de industria, comercio y asuntos públicos". Este es uno de los casos excepcionales (uno análogo era el del desaparecido Tribunal de Tarifas Ferroviarias) en los que personas no letradas ocupan un cargo cuyas atribuciones no difieren mucho de las de un magistrado del Tribunal Supremo, con la importante diferencia de que sólo son nombrados por un número determinado de años (son reelegibles) $\mathrm{y}$, al revés de los magistrados, pueden ser destituídos por el Lord Canciller por incapacidad, mala conducta o la posibilidad de que se produzca prejuicio debido a un conflicto de intereses. Por otra parte, tienen plenas atribuciones judiciales y no son meros consejeros.

Es posible que esta nueva modalidad de tribunal sirva de precedente para el establecimiento de otros en el futuro. De vez en cuando se han formulado propuestas para la creación de un Tribunal Administrativo de Apelación, bien en calidad de Sala de Tribunal Suprema bien como una jurisdicción aparte. Según los proyectos preparados por los defensores de estas propuestas (tales como la "Inns of Court Conservative Association". el profesor W. A. Robson y el autor de este trabajo), se prevé en términos generales que dicho tribunal comprenda en su seno a miembros legos dotados de calificaciones $y$ experiencia especiales en materia administrativa.

17.-Supreme Court of Judicature (Consolidation) Act. 1925. s. 98. (LeY del Iribunat supremo de Judicature (terto refundido). 
Hasta el momento presente, tales proyectos no han merecido aceptación (fueron rechazados en 1931 por la Comisión encargada de definir la competencia de los ministros y recientemente por la Comisión Franks) Y es posible que nunca sean puestos en práctica. Sin embargo, si ello ocurre, la interesante innovación que representa el Tribunal de Prácticas Restrictivas habrá servido para contrarrestar el prejuicio que todavía existe en algunos sectores frente $\alpha$ la atribución de tunciones judiciales a ciudadanos legos.

Bastará lo dicho en este trabajo para probar que, en Inglaterra, los miembros legos del público -si son seleccionados cuidadosa e imparcialmente- no justifican la existencia de dicho prejuicio y son perfectamentecapaces de aportar una contribución útil a la administración de justicia. Es más, no es exagerado decir que el sistema de adjudicación, tal como se ha desarrollado en años recientes, no podría funcionar de manera eficiente sin su colaboración. Sin embargo, a juicio del autor de este artículo, es muy deseable que los legos actúen siempre bajo la orientación de presidentea o colegas que tengan la calidad de letrado. Algunos publicistas temen, en lo que se refiere a los tribunales administrativos, que este factor profesional tenga como resultado una actitud de "legalismo" excesivo; en otras palabras, que redunde en un summum ius, que ha sido descrito por doctrinarios impacientes como mero "sabotaje judicial". Por supuesto, es cierto que la mera calidad de letrado no imparte sabiduría y que un lego juicioso dictamina mejor que un abogado de mentalidad obtusa $y$ estrecha. No obstante, el abogado más incompetente habrá asimilado de su educación y experiencia ciertos principios y métodos que para él son ya instintivos y que no se formulan con la misma facilidad en la mente de un profano animado por un anhelo profundo, pero poco madurado, de que "exista justicia entre hombre y hombre" ( 0 , como es más corriente en la actualidad, justicia entre el hombre $y$ el Estado). Me refiero a principios tales como la neutralidad judicial, la paciencia, la ausencia de prejuicios, la evaluación de las pruebas y de los argumentos opuestos, la resistencia ante la mera emoción y la dirección ordenada de los trabajos judiciales con el objeto de que ambas partes puedan hacerse oir justa e íntegramente. Esta "mentalidad de juez" puede ser asimilada por los profanos y lo es constantemente. Según la experiencia de este autor, la mayoría de los jueces de paz se hace suya firmemente sin dificultades - pero es un hecho que la existencia de un elemento jurídico contribuye grandemente a facilitar su aparición y a reforzar su eficacia. En todo caso, determinados experimentos de postguerra en materia de tribunales que se parecían demasiado a los "tribunales del pueblo", tales como los Tribunales de Arrendamientos, que fueron creados sin prestar bastante atención a los principios de derecho $y$ sin definir con precisión su jurisdicción $y$ atribuciones, no han tenido resultados felices $y$ por lo general están en la actualidad desacreditados.

En cierto modo, resulta paradójico que el elemento lego del sistema jurídico inglés que goza de mayor renombre y que probablemente es el más querido por el público en general -me refiero al Jurado-, se ha convertido en el menos influyente $Y$, con toda posibilidad, en el menos eficaz. 
Sin embargo, en lo que se refiere a las demás esferas de las que se ha hecho mención aquí, puede decirse con confianza que en Inglaterra un número considerable de ciudadanos de ambos sexos - que forman, es cierto, un conjunto selecto, aunque de calificaciones modestas más bien que preeminentes y que pueden quizás ser descritos como de superior calidad respecto del público medio - da pruebas de su fe en la justicia que rige sus vidas al prestar asistencia valiosa, madura $y$, en muchas ocasiones, onerosa $p a-$ ra sí mismos para la mejor marcha de su administración.

C. R. Allen*

* Sir Carleton Kemp Allen, M.C., Q.C., D.C.L., Hon.LL.D. (Glasgow), F.B.A., J.P., miembro de Lincoln's Inn, abogado; miembro emérito del "University College" de Oxford; ex catedrático de Jurisprudencia de la Universidad de Oxford.

Nota.-Este artículo se publica mediante genţl autorización de la 'Comisión Internacional de Juristas" con sede en Ginebra, en cuya Revista apareció por primera vez. 